\title{
Synopsis of Dorstenia (Moraceae) in Rio Grande do Sul, Southern Brazil
}

\author{
BRUNA DE OLIVEIRA BOENI and RODRIGO BUSTOS SINGER \\ Programa de Pós-Graduação em Botânica, Departamento de Botânica, Instituto de Biociências, \\ Universidade Federal do Rio Grande do Sul, Av. Bento Gonçalves, 9500, Bloco IV, Prédio 43433, \\ Sala 214, Campus do Vale, Agronomia, 91501-970 Porto Alegre, RS, Brasil
}

Manuscript received on July 17, 2014; accepted for publication on November 25, 2014

\begin{abstract}
A taxonomic synopsis of Dorstenia (Moraceae) in Rio Grande do Sul (RS), Southern Brazil, is presented. Three species were recorded: $D$. brasiliensis, D. carautae, a new record for the state of RS, and $D$. tenuis. All species are described and illustrated through detailed photos of living specimens. A taxonomic key to separate the species, as well as details on distribution, overall phenology, habitat, conservation status and ecology are presented.
\end{abstract}

Key words: Emygdioa, Lecanium, morphology, South-America, taxonomy.

\section{INTRODUCTION}

Dorstenia Linnaeus is the second largest genus within Moraceae Gaudichaud and differs from the other genera as per its herbaceous habit, inflorescence of the coenanthium type and by the presence of a rhizome. The coenanthium is composed of a well developed and fleshy receptacle, on which the flowers are inserted; it is open and presents a varied format. The genus is currently inserted within the tribe Dorstenieae Dumort. and has a pantropical distribution. As a whole, this group comprises about 105 species (Carauta 1978, Berg and Hijman 1999, Berg 2001). Brazil holds about 37 species, 31 of them being endemic (Romaniuc-Neto et al. 2014). Traditionally (Berg 2001, Berg and Hijman 1999), characteristics of growth habit have been used to set apart the nine sections currently accepted for the genus. A preliminary phylogenetic study (Misiewicz and Zerega 2012) based on molecular

Correspondence to: Bruna de Oliveira Boeni

E-mail: bruboeni@gmail.com characters has suggested that the sections proposed by Berg and Hijman (1999) are not monophyletic. However, this work (Misiewicz and Zerega 2012) presents a restricted and incomplete (ex: several of the type-species of the sections weren't sampled) sampling, making thus premature the rejection of the sections as currently accepted. The sections Lecanium Fischer and Meyer, Dorstenia Fischer and Meyer, and Emygdioa Carauta (as delimitated by Berg and Hijman 1999) are exclusively Neotropical. Section Lecanium comprises shrubby to herbaceous species, with spaced, mostly shortly petiolate leaves. All members of this group are components of the undergrowth and understory of rainforests. Section Dorstenia comprises subcaulescent to caulescent species with long-petioled, large leaves, often bearing lobed to divided leaf blades. Members of this group mostly grow in rainforests, with a few species dwelling in dryer conditions (Berg and Hijman 1999). Section Emygdioa comprises species with relatively small, long-petioled leaves and stems 
with mostly short internodes. Several species of this section are adapted to dry and open vegetation.

Berg (2001) proposed two large SouthAmerican distribution areas for Dorstenia species: the Southeast Dominion, defined by the distribution of Dorstenia brasiliensis Lamarck, and the Northeastern Dominion, defined by the distribution Dorstenia contrajerva Linnaeus. Southern Brazil and neighboring countries like Uruguay, Paraguay and Argentina represent the distributional limit of the genus in the subtropical region.

In Brazil, the species are widely distributed among its biomes (Amazon Forest, Cerrado, Mata Atlântica, Caatinga, Pantanal and Pampa), but most taxa dwell under tropical conditions (Carauta 1978, Berg 2001). Indeed, Tropical Forest biomes have been considered as important biodiversity hotspots (Myers et al. 2000) and as centers of endemism for tropical species. Endemism has often been used as a criterion for choosing areas for conservation purposes (Prevedello and Carvalho 2006). Dorstenia carautae C.C. Berg, for example, is endemic to Brazil and exclusively found in forest environments in advanced stage of regeneration (Berg 2001). In the state of Rio Grande do Sul, Dorstenia tenuis Bonpland ex Bureau and D. brasiliensis were included in the List of Endangered Species according to the state decree no. 42099 of Dec 31, 2002 (Assembléia Legislativa 2013). The present contribution is thus aimed to present a synopsis of the Dorstenia species occurring in Rio Grande do Sul, Southern Brazil, within the austral distributional limits of the genus in the Americas. Additionally, diagnostic morphological (either vegetative or floral) features are highlighted as well as relevant distributional and ecological informations for each species.

\section{MATERIALS AND METHODS}

The descriptions were made by analyzing live specimens and herbarium material. The following herbaria were consulted: F, FLOR, FURB, HAS,
HB, HUCS, HUEFS, ICN, K, MBM, NYBG, P, PACA, PEL, RB, SMDB, SP, SPSF, U, UFP, UPCB, US, acronyms according to Thiers (2013), and UNILASALLE (Herbarium, University La Salle, Canoas, Brazil, not listed in the Index Herbarium). Phenological data and details like coloration, coenanthium and floral features were obtained through the monitoring of specimens, and observations made during field trips complemented by herbarium labels. A detailed photographic record of diagnostic vegetative and floral features was made, aiming to illustrate features or structures not shown or poorly shown in preceding literature. Vegetative and reproductive characteristics were measured based on living and pressed specimens using a pachymeter. The geographical distribution and habitat of the species was obtained from herbarium data, field observations and collections, as well as from literature (Carauta 1978, Carauta et al. 1996, Berg and Hijman 1999, Berg and Simonis 2000, Berg 2001). The popular names cited were obtained from the literature and from annotations on studied pressed specimens. Fieldwork extended from 2011 to 2013. A total of 24 field trips were made in Southern Brazil, state of Rio Grande do Sul. Phytoecological units and transitional vegetation areas in the south of Brazil were classified according to IBGE (2012) and the physiographic subdivisions according to Fortes (1959). The procedures used during these collections follow Mori et al. (1989). The collections were pressed and incorporated into the ICN Herbarium. Infrageneric divisions follow Berg and Hijman (1999) and Berg (2001). Abbreviations for authorities for plant names follow Brummitt and Powell (1992). The protologues and related taxonomic literature were consulted through BHL (2013) and Botanicus.org (2013). Highdefinition digitalized images of type specimens were consulted through Jstor Plants (2013). For morphological terminology, we refer to Radford et al. (1974), Font-Quer (1985) and Harris and Harris (2001). For colour terms, we follow Kornerup and 
Wanscher (1978). Photos of general features of plants, such as habitat and habit were made with the help of a digital camera Sony ${ }^{\circledR}$ Alpha 100 and Sony ${ }^{\circledR}$ Cybershot DSC H7. Details were photographed with the aid of microscopic digital camera Dnt ${ }^{\circledR} 2.0$ DigiMicro Scale and a binocular stereoscope coupled with a Leica ${ }^{\circledR}$ digital camera. In order to assess risk categories according to IUCN criteria (IUCN 2013), the standard procedures suggested by IUCN were followed. The compilation of the data was carried in an outline form from the Live-system software (http://www.liv.fzb.rs.gov.br/). This platform was developed to assess the conservation status of species and preparation of the list of endangered flora in the state of Rio Grande do Sul, according to the IUCN criteria. The geographical distribution maps were produced using software ArcMap ESRI ArcGIS ${ }^{\circledR} 10$.

\section{TAXONOMIC TREATMENT}

Dorstenia L.

Plants herbaceous, prostrated to suffrutescent, monoecious, unbranched or sparsely branched; tuberous rhizome mainly subterranean or stem partly rhizomatous; trichomes often present. Leaves alternate and in spirals or rosulate, membranaceous to coriaceous, lamina basally attached or peltate, entire to divided; margin entire to dentate to crenate; venation pinnate to palmate, brochidodromous to reticulate; stipules foliaceous to subulate, plurinervate to uninervate, persistent. Coenanthium bisexual, but unisexual in some species, solitary in the leaf axils, pedunculate; receptacle discoid, orbicular, elliptic, quadrangular, stellate, lingulate, or lobate, usually with rows of marginal bracts, sometimes with marginal appendages and fringe; trichomes often present on the perianths, among the flowers, and on the fringe. Staminate flowers among the pistillate ones or concentrated in the periphery of the flowering face; tepals 2-4, almost free; stamens 2-3. Pistillate flowers sessile; perianth tubular, only the upper part free, entire, 2-3 lobed; ovary immersed in fleshy receptacle; stigmas bifid, shortly filiform, often unequal in length. Fruit achene, mostly with tuberculate endocarp body. Seeds without endosperm, triangular heel, transverse and uncinate embryo, cotyledons thin, fan-shaped.

\section{Artificial key to the Dorstenia species native to Rio Grande do Sul, Southern Brazil}

1. Internodes elongate, more than $1.5 \mathrm{~cm}$ long, suffrutescent, leaves not rosulate. Dorstenia carautae

1 '. Internodes short, less than $0.5 \mathrm{~cm}$ long, straight or prostrated, leaves rosulate.

2. Lamina cordiform, coenanthium triangular in shape. Dorstenia tenuis $2 '$. Lamina oblong to elliptic, or ovate to obovate or oblate, coenanthium discoid to orbicular. Dorstenia brasiliensis

1. Dorstenia carautae C.C. Berg Proc. Kon. Ned. Akad. Wetensch. C 89(2): 136. 1986. Figures 1A-F and $2 \mathrm{~A}-\mathrm{H}$.

Type: BRAZIL. São Paulo: Eldorado, nr. Gruta da Tapagem, 22 January 1971, Carauta 1277 (holotype RB!, isotypes AC, COL, E, F, GH, GUA, K[image!], NCU, SING, SP, U[image!], US[image!], UT, ZA).

Herb suffrutescent, 25-80 cm tall; stem partly repent to rhizomatous, densely puberulous to hirtellous; internodes elongate, more than $1.5 \mathrm{~cm}$ long. Leaves tending to distichous; lamina oblong to elliptic, $3-16 \times 1.8-7.5 \mathrm{~cm}$, membranaceous to chartaceous; apex acute to acuminate; base acute to rounded; margin dentate to crenate in the young leaves and repand in the old leaves; upper surface scabrous with conical trichomes or pilose to glabrous; lower surface puberulous with straight to uncinate trichomes, mainly on the veins, or hirtellous especially in primary venation; venation brochidodromous, 6-11 vein 
pairs; petiole 1-4 cm long; puberulous with straight or uncinate trichomes; stipules subulate, 0.1-0.4 cm, puberulous. Coenanthium generally quadrangular, inside of receptacle green, centrally attached, 1-2 cm diameter; outside also green and puberulous; at the margin there are bracts in 2-4 rows or overlapping, ovate to orbicular, green to purplish, puberulous, ciliolate, $0.07 \mathrm{~cm}$ long. Staminate flowers, $0.1 \mathrm{~cm}$ long, inserted between the pistillate ones, $0.1 \mathrm{~cm}$ long; tepals 2, stamens 2, anthers violet white, stigmas white. Peduncle short, 0.2-1.2 cm long, green, puberulous. Fruit, $0.15 \times 0.2 \mathrm{~cm}$.

Specimens examined: BRAZIL. Rio Grande do Sul: Taquara, Fazenda Fialho, 2943'44.51"S, $50^{\circ} \quad 54^{\prime} 53.04 " \mathrm{~W}$, with inflorescences, in semideciduous seasonal forest, near river, 29 April 2011, S. Bordignon s.n. (ICN 182363); Taquara, Pega Fogo, with inflorescences, in semideciduous seasonal forest, 20 November 2001, A. Knob and $S$. Bordignon 6932 (UNILASALLE).

Additional specimens examined: BRAZIL. Paraná: Adrianópolis, Barra do Rio Pardo, 05 April 1976, G. Hatschbach 38550 (MBM); Antonina, Rio Cotia, 24 March 1966, G. Hatschbach 14137 (MBM); Cerro Azul, June 1996, J.M. Silva 782 (HUEFS); Guaraqueçaba, Fazenda Abobreira, 15 October 1970, G. Hatschbach 22461 (MBM); Guaratuba, Cabeceiras Rio Boguassú, 23 October 1958, G. Hatschbach 5185 (MBM); Morretes, Porto de Cima, P. Dusén 14617 (MBM); Morretes Olimpo, Parque Estadual Pico Marumbi, 24 August 2010, M. Verdi 5486 (FURB); Paranaguá, Morro do Inglês, 01 January 2002, O.S. Ribas 4221 (MBM); Quatro Barras, Rio do Corvo, 12 January 1967, G. Hatschbach 15700 (MBM); Tijucas do Sul, 30 September 2009, M.D.M. Vianna Filho 2028 (RB). Santa Catarina: Anitápolis, Rio da Prata, 06 July 2010, M. Verdi 5201 (FURB); Apiúna, Jundiá, 19 March 2010, A. Korte 2282 (FURB); Ascurra, Guaricanas, 15 March 2010, A. Korte 2848 (FURB); Camboriú, Cobra Fria, 09 November 2010, A. Korte 4904 (FURB); Camboriú, Rio do
Meio, 11 November 2010, A. Korte 4938 (FURB); Garuva, Estrada Bonita Serra do Quiriri, 24 November 2010, A. Korte 5070 (FURB); Ibirama, Caminho Moema, 07 April 2010, A. Korte 2528 (FURB); Jacinto Machado, Cará, 26 September 2009, M. Verdi 2750 (FURB); José Boiteux, Rio Laeisz, 14 April 2010, A. Korte 2729 (FURB); Major Gercino, Reserva Indígena Águas Claras, 06 October 2010, A. Korte 4554 (FURB); Morro Grande, Três Barras, 23 November 2009, M. Verdi 3111 (FURB); Nova Trento, Rio Veado, 29 September 2010, A. Korte 4509 (FURB); Orleans, Rio Mirador, 12 March 2010, M. Verdi 3898 (FURB); Paulo Lopes, Laranjal, 30 April 2010, M. Verdi 4543 (FURB); Presidente Nereu, Rio Pequeno, 08 October 2009, A. Korte 415 (FURB); Rodeio, São Pedro, 30 March 2010, A. Korte 2398 (FURB); Siderópolis, Barragem do Rio São Bento, 05 November 2009, M. Verdi 3048 (FURB); Witmarsum, Krauer Central, 13 April 2010, A. Korte 2698 (FURB); Vitor Meireles, Barra da Prata, 03 June 2010, A. Korte 3586 (FURB). São Paulo: Barra do Turvo, Ribeirão do Meio, 14 January 1999, J.M. Silva 2868 (MBM); Cardoso, Rio Perequê, 10 November 1980, E. Forero 8782 (RB); Iporanga, Parque Estadual Turistico do Alto Ribeira, 30 September 2009, J.R.L. Godoy et al. 532 (SPSF); Juréia, 29 September 2009, M.D.M. Vianna Filho 2027 (RB); Peruíbe, Estação Ecológica da Juréia, October 1993, M. Sobral 7584 (MBM); Ubatuba, 28 September 2009, M.D.M. Vianna Filho 2023 (RB).

Distribution: Endemic to Brazil. Formerly considered to be restricted to the States of São Paulo, Paraná and Santa Catarina (Berg and Hijman 1999, Berg 2001). This is a new record of $D$. carautae, a novelty for the Rio Grande do Sul's Flora, thereby increasing the range of occurrence of the species in Brazil (Fig. 8). In the states of São Paulo, Paraná and Santa Catarina, D. carautae occurs in dense ombrofilous forest, in Rio Grande do Sul it was found only in semideciduous seasonal forest. 

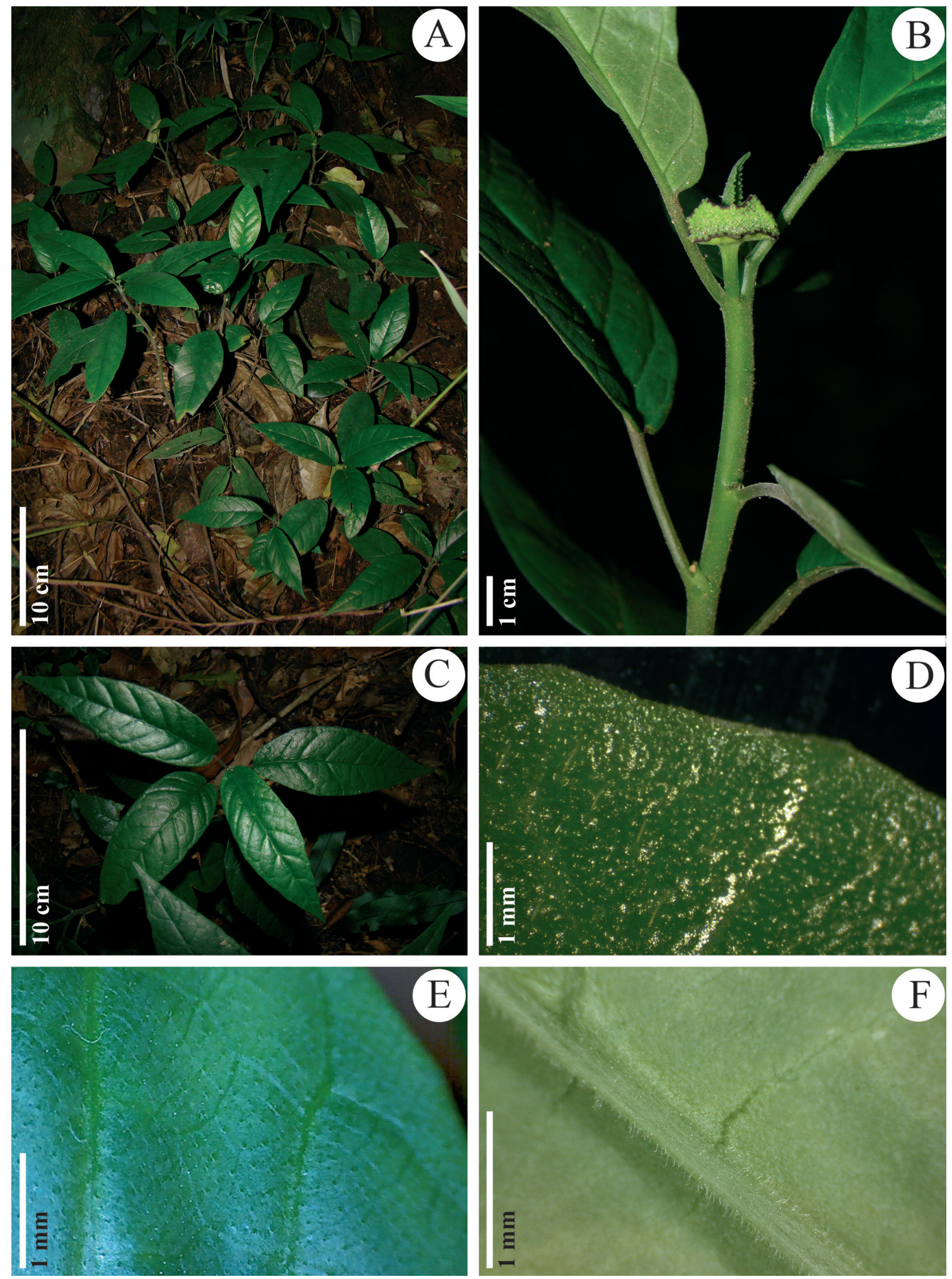

Figure 1 - Dorstenia carautae C.C. Berg. A. Habit. B. Detail of stem and leaves; notice the elongate internodes. C. Detail of the plant. D. Adaxial surface of leave with sparse trichomes. E. Adaxial surface of leave with conical trichomes. F. Abaxial surface of leave, puberulous. Scale bars: $\mathbf{A}$ and $\mathbf{C}=10 \mathrm{~cm} ; \mathbf{B}=1 \mathrm{~cm} ; \mathbf{D}-\mathbf{F}=1 \mathrm{~mm}$. 

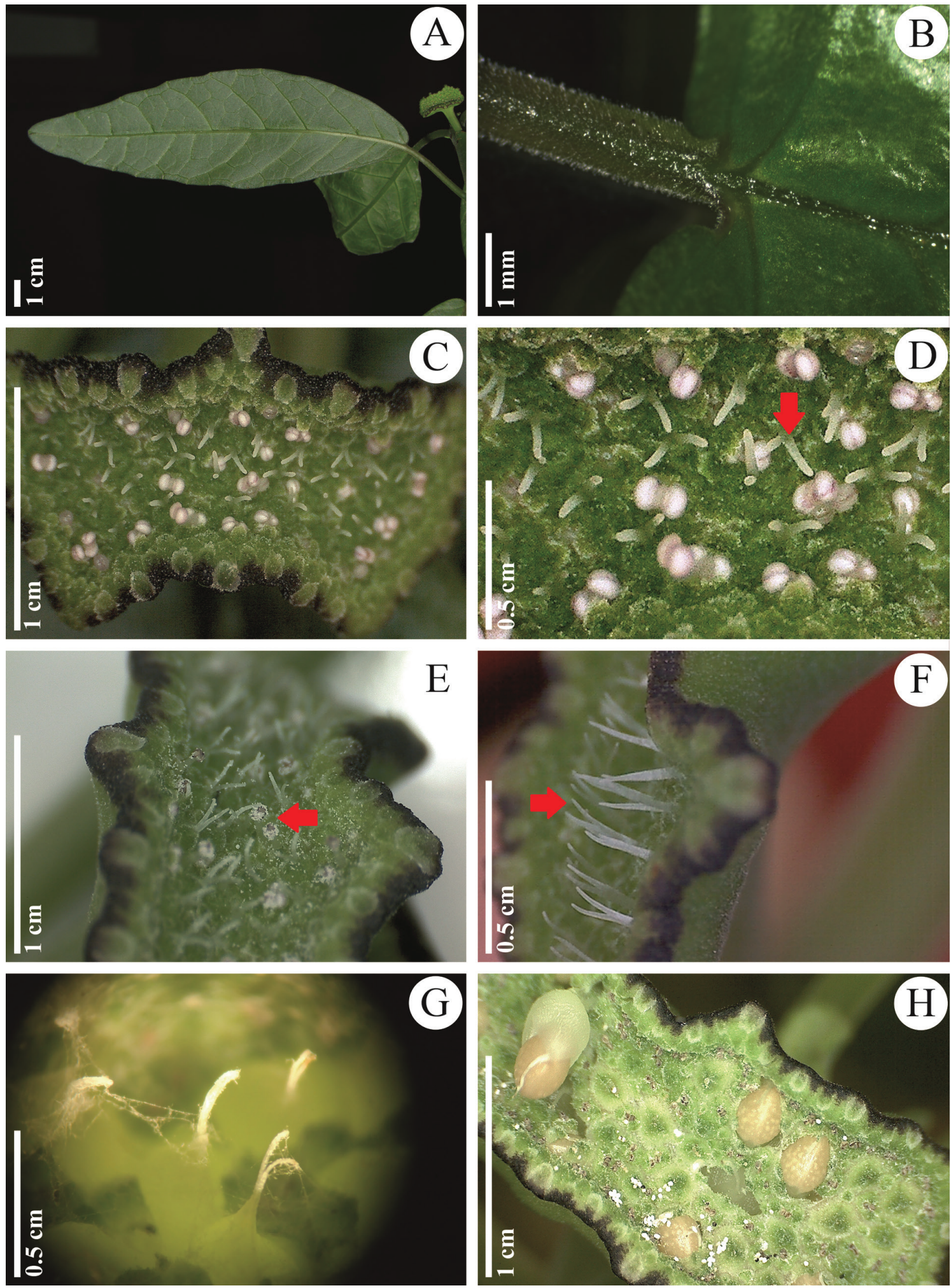

Figure 2 - Dorstenia carautae C.C. Berg. A. Veins brochidodromous. B. Base of leaf blade. C. Coenanthium, bracts in rows. D. Detail of staminate and pistillate (arrow) flowers. E. Staminate flowers at anthesis (arrow). F. Pistillate phase (arrow). G. Fruit development. H. Mature achenes. Scale bars: $\mathbf{B}=1 \mathrm{~mm} ; \mathbf{A}, \mathbf{C}, \mathbf{E}, \mathbf{H}=1 \mathrm{~cm} ; \mathbf{D}, \mathbf{F}-\mathbf{G}=0,5 \mathrm{~cm}$. 
Phenology: The coenanthia are fragile and usually small. They may or not present overlapping of sexual phases. The coenanthia exhibit variations in shape during their developing. Fruit production occurred twice a year between the months of May and June and again in the months of December and January.

Habitat and ecology: Occurs in forests, from middle to advanced process of regeneration, growing in shady and humid understory; usually near water bodies. According to Berg (2001), this species is found at low elevations. In Rio Grande do Sul, it was collected at an altitude of $216 \mathrm{~m}$.

Conservation status: According to the IUCN (2013) criteria, the species is considered, at the State of Rio Grande do Sul as critically endangered: CR B2b(ii) - the estimated area of occupancy is less than $10 \mathrm{~km}^{2}$, and the field observations indicate a continuing decline of habitat quality; - the size of the observed population was of some hundreds of mature individuals. Therefore, D. carautae should be included in the Official List of Threatened Species of Rio Grande do Sul's Flora. In addition, the whole distribution of this taxon in Brazil coincides with the endangered Atlantic Forest biome, which currently presents less than 7\% of its original cover (Myers et al. 2000).

Notes: This species belongs to the section Lecanium Berg and Hijman (1999). This species is the only of this section extending to Rio Grande do Sul. Among the Dorstenia spp. in this state, D. carautae is unmistakable because of its erect caulescent habit.

2. Dorstenia tenuis Bonpl. ex Bureau Prodr. [A. P. de Candolle] 17: 264. 1873. Figures 3A-H and 4A-H.

Type: ARGENTINA. Corrientes: Without locality, Bonpland 973 (holotype P[image!], isotypes G, MPU).

Herb straight, stem subterranean, rhizome 5-7 cm long, densely puberulous; internodes short, less than $0.5 \mathrm{~cm}$ long. Leaves rosulate; lamina cordiform, $2-11 \times 2-8 \mathrm{~cm}$, membranaceous to chartaceous; apex obtuse; base cordate; margin entire to crenate; upper surface strigose to scabrous; lower surface puberulous, especially in the primary and secondary veins, with uncinate and straight trichomes; venation cladodromous, 4-6 vein pairs; petiole $7-15 \mathrm{~cm}$ long, puberulous with straight trichomes; stipules, 0.2-0.4 cm, puberulous. Coenanthium generally triangular, inside of a violet-brown receptacle, centrally attached, 0.4-2 cm diameter; outside green and puberulous; at the margin there are bracts in 3 rows or overlapping, ovate to orbicular, green to violet, puberulous, ciliolate, $0.05 \mathrm{~cm}$ long. Staminate flowers, 0.01 $\mathrm{cm}$ long, inserted between the pistillate ones, 0.01 $\mathrm{cm}$ long, sometimes aggregated at the thickened and bent edges; tepals 2, stamens 2, anthers white, stigmas pale violet. Peduncle long, 1-9 cm long, generally green, sometimes violet, puberulous. Fruit, $0.1 \times 0.15 \mathrm{~cm}$.

Specimens examined: BRAZIL. Rio Grande do Sul: Agudo, Cerro Agudo, September 1985, M. Sobral 4327 (ICN); Caçapava do Sul, Guaritas, 25 November 1994, C. Mondin 921 (ICN); Caçapava do Sul, 09 December 2005, V.F. Kinupp and H. Lorenzi 3125 (ICN); Caçapava do Sul, Rio Camaquã, 20 March 2009, G. Dettke 158 (ICN); Caçapava do Sul, Guaritas, 31 October 2011, B.O. Boeni 17 (ICN); Campestre da Serra, 19 January 2013, B.O. Boeni 76 (ICN); Canela, Ecoparque Sperry, 13 December 2011, G. Dettke 1000 (ICN); Derrubadas, 16 October 1987, N. Silveira 9435 (HAS); Derrubadas, Parque Estadual Turvo, 26 October 2004, C.D. Inácio 31 (ICN); Derrubadas, Parque Estadual do Turvo, 25 October 2011, B.O. Boeni 14 (ICN); Dois Irmãos, 25 November 1935, B. Rambo s.n. (PACA 2153); Farroupilha, 13 July 1949, B. Rambo s.n. (PACA 42531); Jaguari, 04 December 1973, B. Irgang et al. s.n. (ICN 27124); Lagoa Vermelha, 09 February 2012, B.O. Boeni 30 (ICN); Marcelino Ramos, 10 October 1988, J.A. Jarenkow 955 (PACA); Montenegro, 17 August 

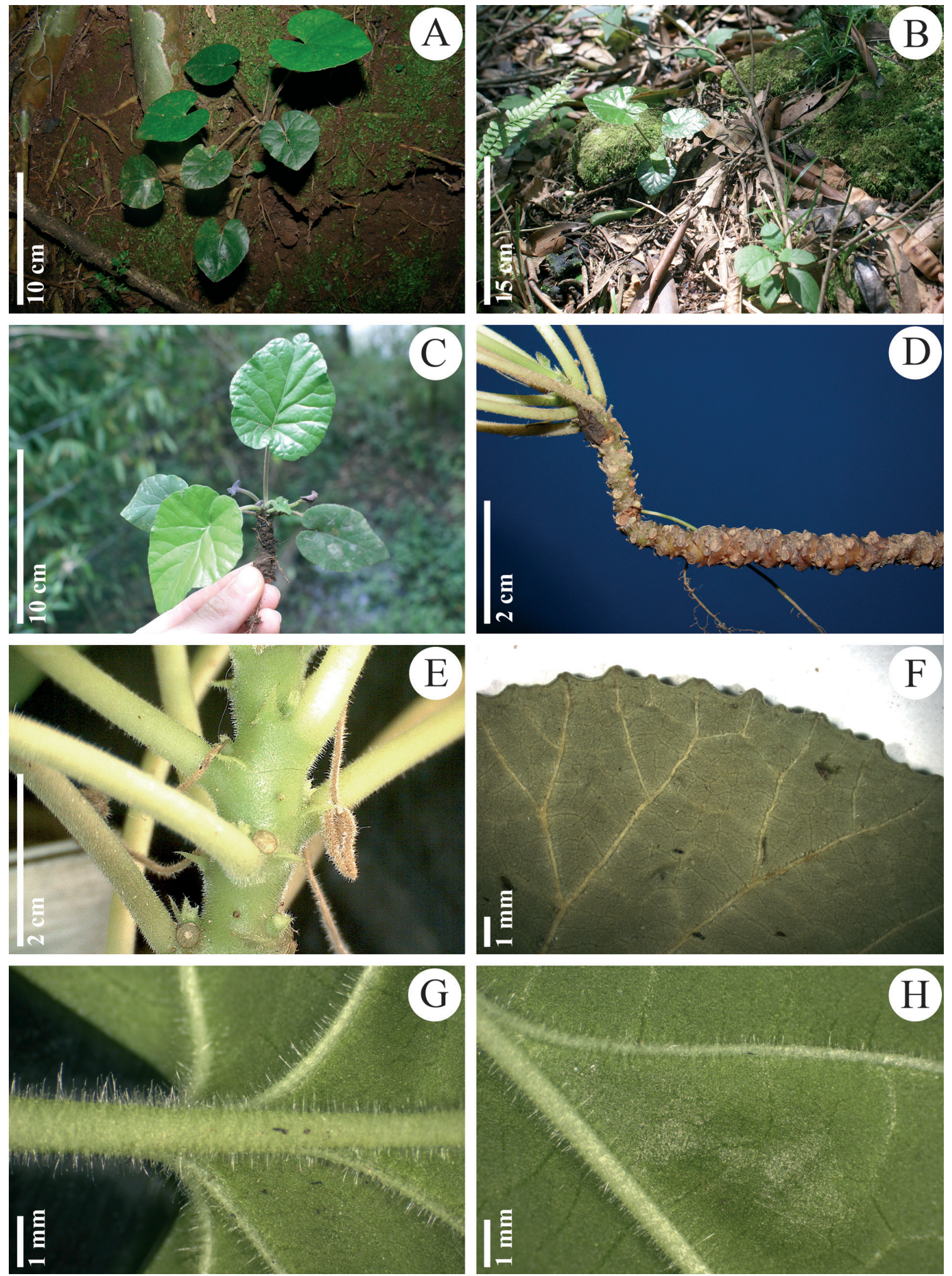

Figure 3 - Dorstenia tenuis Bonpl. ex Bureau. A. Habitat. B. Habit. C. Herb with inflorescences. D. Rhizome. E. Short internodes and stipules. F. Veins cladodromous and margin crenate. G. Base cordate. H. Abaxial surface of leave, puberulous. Scale bars: A, $\mathbf{C}=10 \mathrm{~cm} ; \mathbf{B}=15 \mathrm{~cm} ; \mathbf{D}-\mathbf{E}=2 \mathrm{~cm} ; \mathbf{F}-\mathbf{H}=1 \mathrm{~mm}$. 

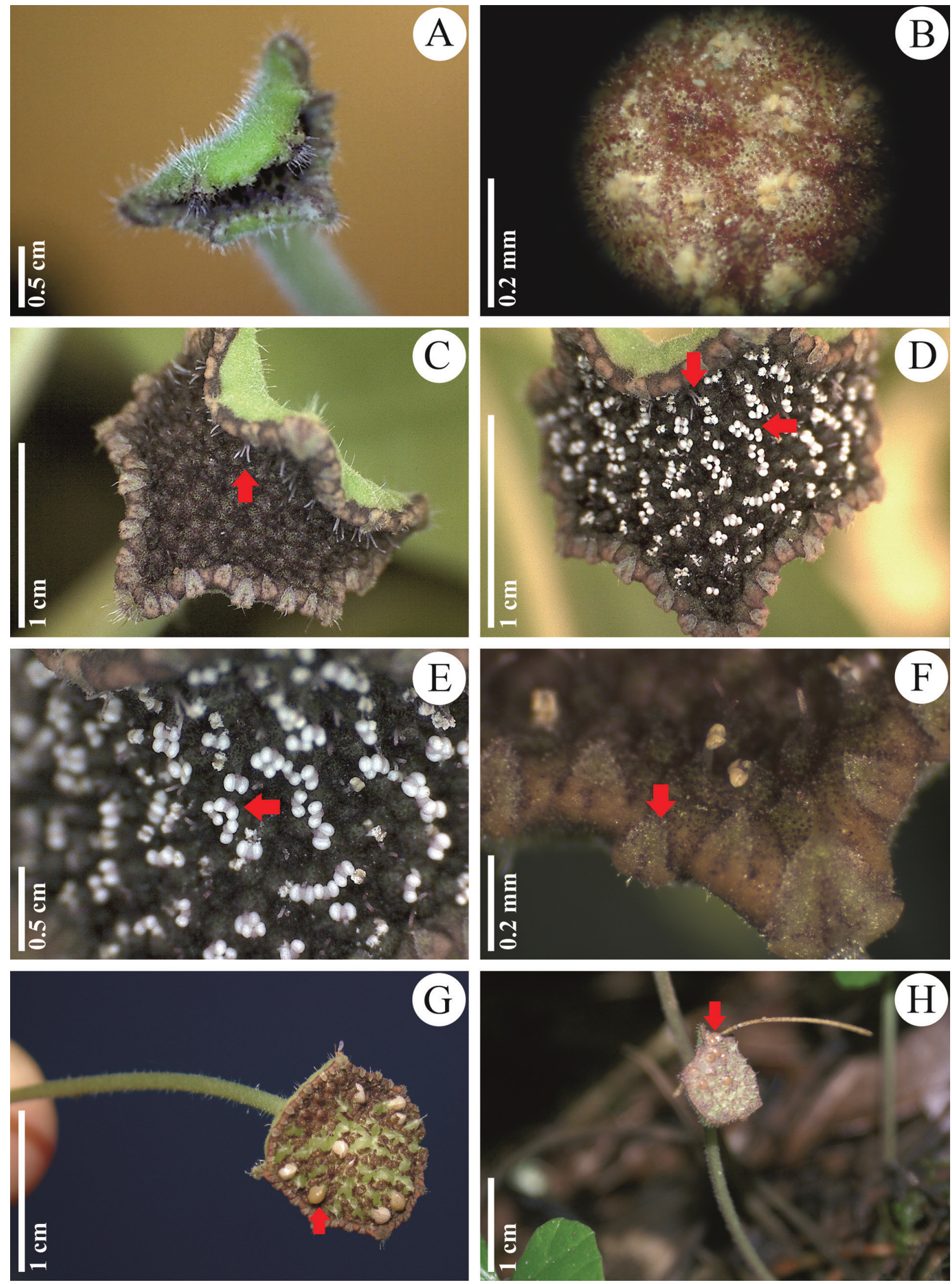

Figure 4 - Dorstenia tenuis Bonpl. ex Bureau. A. Coenanthium in early development. B. Detail of coenanthium. C. Pistillate phase (arrow). D. Staminate and pistillate phase (arrow). E. Detail of anthers. F. Bracts at the margin (arrow). G. Fruit development (arrow). H. Mature achene (arrow). Scale bars: A, E =0,5 cm; C-D, G-H = $1 \mathrm{~cm} ; \mathbf{B}, \mathbf{F}=0,2 \mathrm{~mm}$. 
1949, B. Rambo s.n. (PACA 42980); Muitos Capões, 10 February 2012, B.O. Boeni 31 (ICN); Novo Hamburgo, 23 June 1949, B. Rambo s.n. (PACA 42117); Parobé, Santa Cristina do Pinhal, 21 October 1987, S. Diesel s.n. (PACA 71193); Piratini, 02 December 2012, B.O. Boeni 70 (ICN); Pinhal da Serra, 19 September 2013, B.O. Boeni 95 (ICN); Santa Cruz do Sul, Trombudo, 01 January 1978, J.L. Waechter 699 (ICN); Santa Rosa, February 1950, A. Spies s.n. (PACA 47390); Santa Tereza, 14 May 2013, F. Gonzatti 689 (ICN); Santana da Boa Vista, 02 December 2012, B.O. Boeni 71 (ICN); Tenente Portela, P. Brack 1808 (ICN); Vacaria, Encanado, rio Pelotas, 05 May 2005, G. Pereira-Silva 10060 (SP); Santa Tereza, Reserva Brum, 23 February 2013, E. Valduga 496 (HUCS).

\section{Additional specimens examined:} ARGENTINA. Missiones: Candelaria, Loreto, 17 October 1945, J.E. Montes 1326 (RB); Dep. Guaraní, Sendero, 16 September 1998, H.A. Keller 30 (UPCB). BRAZIL. Paraná: Cerro Azul, Rio Bom Sucesso, 22 November 1979, G. Hatschbach 42576 (NYBG); Foz do Iguaçu, Rio Tamanduá, Parque Nacional do Iguaçu, 7 May 1949, A.P. Duarte 1811 (MBM); Guaíra, Sete Quedas, 7 September 1981, G. Hatschbach 43989 (MBM). Santa Catarina: Concórdia, Volta Grande, 27 December 1997, J.A. Jarenkow 3709 (FLOR); Itapiranga, 06 February 1951, B. Rambo 49892 (ICN); São Miguel do Oeste, 14 June 1980, L.B. Smith 12786 (NYBG).

Distribution: Occurs in Brazil, in the states of Paraná, Santa Catarina and Rio Grande do Sul (Fig. 8) and in the neighboring Argentina, Paraguay and Uruguay (Berg 2001, Carauta 1978). In Rio Grande do Sul, D. tenuis occurs in semideciduous seasonal forest and mixed ombrofilous forest and doesn't occur in dense ombrofilous forest.

Phenology: The coenanthia are fragile and usually small. The staminate and pistillate flowers may bloom or not at the same time. Staminate and pistillate flowers ripen in November and fruiting occurs in May. During the cold season the production of coenanthia decreases.

Habitat and ecology: Grows in dark and humid places, usually near water bodies, at the forest understory. It is common for this species to develop near the base of trees or on substrates like rocks and remains of dead trunks. This species dwells in forests at medium and advanced stages of regeneration, being very sensitive because it is not likely to occur in disturbed environments. It is found at low altitudes, between 253 to $615 \mathrm{~m}$.

Conservation status: This species was considered at risk of extinction, in the Endangered category, at the regional list of endangered species of Rio Grande do Sul, according to the state decree no. 42099 of Dec 31, 2002 (Assembléia Legislativa 2013). It was also included into the National list of threatened flora of 2008 (Ministério do Meio Ambiente 2008) being excluded from the current version (Romaniuc-Neto et al. 2013). However after a reevaluation of this taxon in Rio Grande do Sul according to the IUCN (2013) criteria, the species is considered Least Concern (LC) — not qualifying for a higher risk category, being an abundant and widely distributed taxon. During the last years we have found several and abundant populations, all scattered along the Serra do Sudeste and Alto Uruguay, therefore, D. tenuis should not be included in the Official List of Threatened Species of Rio Grande do Sul's Flora.

Notes: Belongs to the Section Emygdioa (Berg and Hijman 1999). Popularly known as violeta-damontanha, contra-erva and canapia.

3. Dorstenia brasiliensis Lam. Encycl. [J. Lamarck and al.] 2(1): 317. 1786. Figures 5A-H and 6A-H.

Type: URUGUAY. Montevideo: Without locality, Commerson s.n. isotype P 00710376 [image!]; isotypes F[image!], G, MPU).

Dorstenia brasiliensis Lamarck var. tubicina (Ruiz and Pavón) Chodat and Vischer. Type:PERU. Huánuco: Nr. Chinchao, Ruiz \& Pavón s.n. 

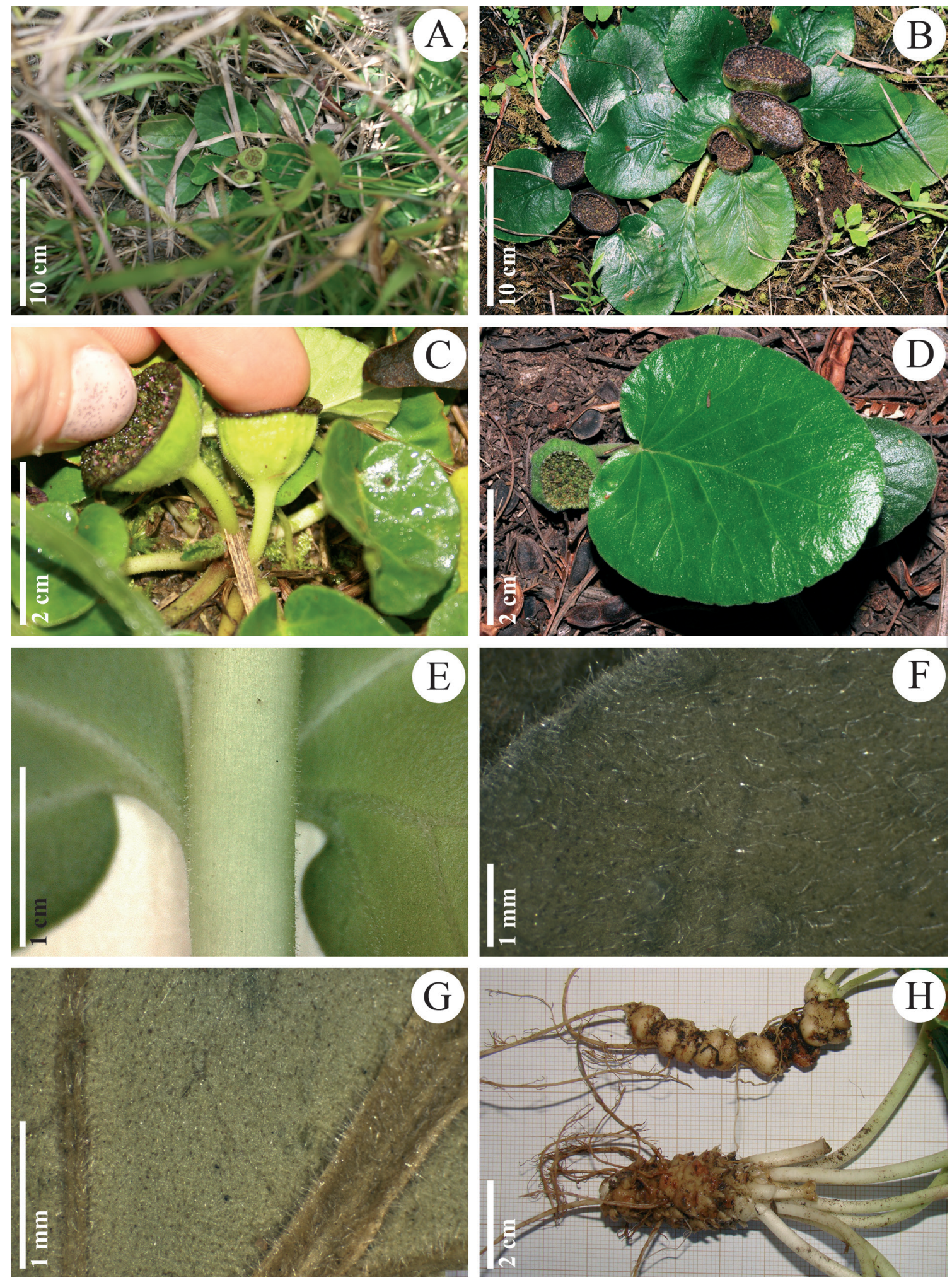

Figure 5 - Dorstenia brasiliensis Lam. A. Habit. B. Prostrate leaves. C. Coenanthium, outside of receptacle. D. Lamina of leave, ovate. E. Cordate base of leaf blade. F. Adaxial surface of leave. G. Abaxial surface of leave. H. Rhizome. Scale bars: $\mathbf{A}$ and $\mathbf{B}=10 \mathrm{~cm} ; \mathbf{C}-\mathbf{D}, \mathbf{H}=2 \mathrm{~cm} ; \mathbf{E}=1 \mathrm{~cm} ; \mathbf{F}$ and $\mathbf{G}=1 \mathrm{~mm}$. Photos $\mathbf{B}$ and $\mathbf{D}$ : S. Bordignon. 

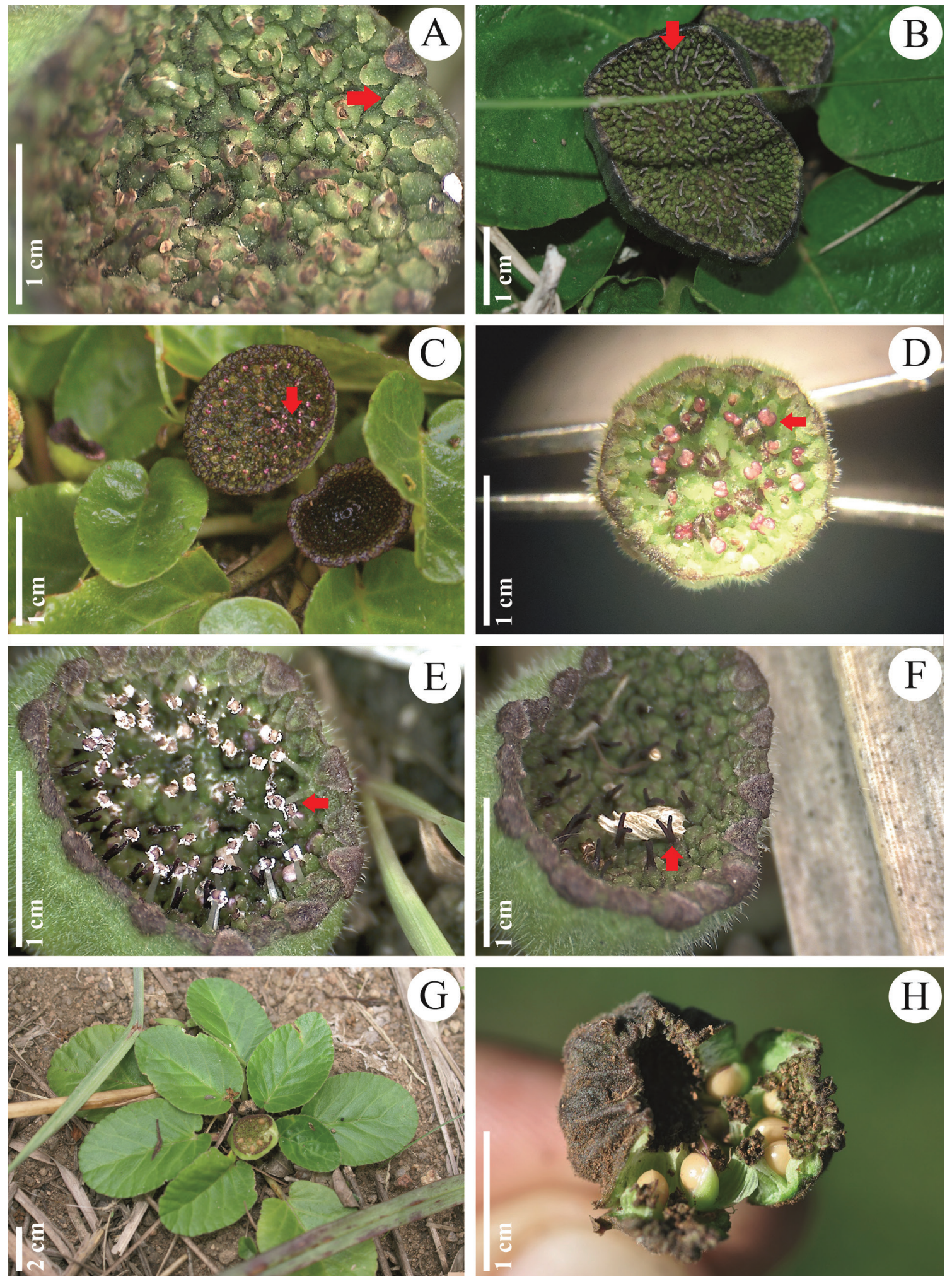

Figure 6 - Dorstenia brasiliensis Lam. A. Coenanthium, bract rows (arrow). B. Pistillate phase, before fertilization (arrow). C. Staminate phase (arrow). D. Mature stamens (arrow). E. Detail of anthesis (arrow). F. Pistillate phase, after fertilization (arrow). G. Fruit development. H. Mature achenes. Photo H: S. Bordignon. Scale bars: A-F, H=1 cm; $\mathbf{G}=2 \mathrm{~cm}$. 
(holotype MA[image!]; isotypes B, BM[image!], F[image!], G); Dorstenia pernambucana Arruda. Type:-BRAZIL. Pernambuco: Tapera, Pickel 1336 (neotype designated by Carauta (1978)); Dorstenia infundibuliformis Loddiges. Type: Bot. Cab. 18: t. 1784; Dorstenia montevidensis Miquel. Type:-URUGUAY. Montevideo, Tweedie s.n. (holotype, K[image!]); Dorstenia tomentosa Fischer and Meyer. Type:-BRAZIL. Riedel s.n. (holotype LE[image!]); Dorstenia brasiliensis Lamarck var. tomentosa Fisch. and C.A. Mey. in Hassler. Type:-BRAZIL. Mato Grosso: Rio Pardo, Riedel 527 (holotype, LE[image!]); Dorstenia brasiliensis Lamarck var. major Chodat, in Chodat and Hassler. Type:-PARAGUAY. Hassler E. 7847 (Isotype P[image!]); Dorstenia tubicina Lamarck var. genuina) forma major (Chodat) Hassler. Type:PARAGUAY. Rio Apa, November, Hassler 7847 (holotype, G; isotypes, BM, G, K, MICH, MO, NY, P, RB[image!]); Dorstenia montana Herzog. Type:-BOLIVIA. Santa Cruz: Samaipata, March 1911, Herzog 1729 (holotype B; isotypes G, S[image!]); Dorstenia brasiliensis Lamarck var. palustris Hassler. Type:-PARAGUAY. Depto. Central, nr. Lago de Ypacarai, June, Hassler 3023 (holotype G; isotype G); Dorstenia tubicina Ruiz and Pavón var. opifera (Martius) Hassler f - subexcentrica Hassler. Type:-PARAGUAY. Depto. Central, nr. Lago de Ypacarai, Sep, Hassler 927 (holotype, G; isotypes, BM, G, K, NY, P); Dorstenia brasiliensis Lamarck var. guaranitica Chodat and Vischer. Type:-PARAGUAY. Depto. Cordillera, San Bernardino, Chodat and Vischer 247 (lectotype G); Dorstenia brasiliensis Lamarck forma balansae Chodat. Type:-PARAGUAY. Depto. Guaíra, Dona Juana, nr. Villarica, 17 September 1874, Balansa 1983 (holotype, G; isotype, P[image!]); Dorstenia sabanensis Cuatrecasas. Type. VENEZUELA. Guárico: nr. Calabozo, July 1954, Aristeguieta and Hernández 2316 (holotype, F; isotype, VEN); Dorstenia schulzii Carauta,Valente and Dunn de Araujo. Type:-ARGENTINA. Formosa: Formosa, 7 May 1964, A. G. Schulz 18318 (holotype, in herb. A. G. Schulz; isotypes F[image!], IPA, LIL, RB[image!]); Dorstenia amazonica Carauta, C. Valente and Barth. Type:-BRAZIL: Goiás: Araguaia, Rio Boa Vista, Fazenda Boa Vista, 28 January 1976, Carauta 1863 (holotype, RB [image!]; isotypes, GUA, HB, MICH, R, US).

Herb prostrated, stem subterranean, rhizome 1-6.3 cm long, densely puberulous; internodes, less than $0.5 \mathrm{~cm}$ long. Leaves rosulate; lamina oblong to elliptic, or ovate to obovate to oblate, $1-5 \times 1.4-6.1 \mathrm{~cm}$ long, membranaceous to coriaceous; apex rounded to obtuse; base cordate to obtuse; margin entire to sinuate or crenate; upper surface tomentose to glabrescent; lower surface puberulous to hirtelous, especially in the primary and secondary veins, with straight trichomes; venation craspedodromous, 4-8 vein; petiole $0.3-6.8 \mathrm{~cm}$ long, puberulous to hirtelous with uncinate trichomes; stipules, 0.2-0.7 cm, puberulous. Coenanthium discoid to orbicular, inside of green or violet-brown receptacle, centrally attached and concave, 0.5-3 cm diameter; outside green or brown and puberulous; at the margin there are bracts in 1-2 rows or overlapping, ovate, violet, puberulous, ciliolate, $0.02-0.1 \mathrm{~cm}$ long. Staminate flowers, $0.2 \mathrm{~cm}$ long, inserted between the pistillate ones, $0.2 \mathrm{~cm}$ long; tepals 2, stamens 2, anthers pink, stigmas grayish-white before fertilization and violet or dark violet after fertilization. Peduncle short, $0.2-1.5(-7) \mathrm{cm}$, green, puberulous to hirtelous. Fruit, $0.15 \times 0.2 \mathrm{~cm}$.

Specimens examined: BRAZIL. Rio Grande do Sul: Alegrete, 26 December 1958, J. Mattos 6310 (HAS); Alegrete, 25 November 2007, E. Freitas 416 (ICN); Alegrete, Cerro do Tigre, 07 December 2012, G.D.S. Seger 1115 (ICN); Bagé, November 1956, D. Tubino 80 (HAS); Bagé, 15 May 2011, A. Sanguinetti s.n. (ICN 182409); 
Caçapava do Sul, 30 May 1976, M.L. Porto and B. Irgang 2204 (ICN); Caçapava do Sul, 21 March 1992, C. Schlindwein 1362 (UFP); Caçapava do Sul, 09 November 1996, J.A. Jarenkow 3229 (PEL); Caçapava do Sul, 01 November 1997, J.A. Jarenkow and E.N. Garcia 3606 (PEL); Caçapava do Sul, 27 August 1998, C. Mondin 1414 (PACA); Caçapava do Sul, 31 October 2011, B.O. Boeni 16 (ICN); Canguçu, 21 April 2005, F.J.M. Caporal s.n. (ICN 142626); Encruzilhada do Sul, 11 August 1982, J. Mattos 23514 (HAS); Guaíba, 01 August 1982, N. Matzembacker s.n (HAS 14648); Guaíba, 12 September 1993, N.I. Matzenbacher s.n. (ICN 103657); Guaíba, 03 December 2005, L.F. Lima 186 (ICN); Guaíba, 05 May 2011, B.O. Boeni 05 (ICN); Herval, 26 October 2006, M. Grings 579 (ICN); Lavras do Sul, 12 February 1971, A. Sehnem 1971 (PACA); Lavras do Sul, 05 October 1984, M. Sobral 3129 (ICN); Pantano Grande, Rincão Gaia, 31 August 1991, J. Larocca s.n. (PACA 95986); Porto Alegre, 13 October 1932, B. Rambo 428 (SP); Porto Alegre, 11 September 1942, J. E. Leite 413 (SP); Porto Alegre, 10 October 1946, B. Rambo .s.n. (S 22367); Porto Alegre, 10 November, 2008, R. Setubal 810 (ICN); Quaraí, Cerro do Jarau, 01 May 2013, J.G. Silva s.n. (ICN 182327); Rio Grande, 11 July 1994, J.A. Jarenkow 2392 (PEL); Santa Maria, 27 October 1935, G. Rau s.n. (SMDB 103); Santa Maria, 02 August 1959, R. Beltrão s.n. (SMDB 1048); Santa Maria do Herval, 29 November 1999, A.A. Ohlweiler s.n. (PACA 95985); Santa Maria, 20 September 2011, B.O. Boeni 09 (ICN); Santana da Boa Vista, 06 June 1995, J.A. Jarenkow and M. Sobral 2672 (PEL); Santana da Boa Vista, 02 December 2012, B.O. Boeni 69 (ICN); Santana do Livramento, 10 February 1972, J.A. Cruz s.n. (HB 57915); Santana do Livramento, 09 November 2008, $R$. Trevisan et al. 1017 (ICN); Santiago, 29 July 1974, Quintas 1021 (RB); Santiago, 15 January 2013, C. Vogel-Ely et al. 42 (ICN); São Sepé,
01 September 1986, J. Mattos 29869 (HAS); Uruguaiana, 14 February 1985, F.R. Galvani s.n. (PACA 67970); Viamão, Parque Estadual de Itapuã, 29 November 2012, B.O. Boeni 68 (ICN).

Distribution: Distributed in Uruguay, Argentina, Brazil, Bolivia, Peru, Colombia, Venezuela, Trinidad, Guyana and French Guiana. In Brazil, it occurs in Amapá, Amazonas, Bahia, Ceará, Distrito Federal, Goiás, Maranhão, Mato Grosso, Mato Grosso do Sul, Minas Gerais, Pará, Paraíba, Paraná, Pernambuco, Roraima, Rio Grande do Sul and São Paulo (Berg and Hijman 1999, Berg 2001). In Rio Grande do Sul (Fig. 8) it occurs only in the Pampas, in low altitude grasslands.

Phenology: The mature coenanthia are generally robust and prostrate. The sexual phases may overlap or not. The coenanthia exhibit variations in shape during their reproductive functions. Fruiting occurred between the months of March to May.

Habitat and ecology: This species dwells in dry environments, in savannas and grasslands, in sandy soils or rocky outings. Dorstenia brasiliensis is often found growing along the sandy and rock fields, with grasses and cacti, respectively. It is found at low altitudes, only at a maximum of 289 $\mathrm{m}$. In high altitude grasslands, no specimens were found, probably due to low temperatures.

Conservation status: Considered at risk of extinction in the vulnerable $(\mathrm{Vu})$ category according to state decree no. 42099 of Dec 31, 2002 (Assembléia Legislativa 2013). However after the reevaluation of this taxon in Rio Grande do Sul according to the IUCN (2013) criteria, the species is considered Least Concern: (LC)not qualifying for a higher risk category, being an abundant and widely distributed taxon. During the last years we have found several and numerous populations of this species along the Serra do Sudeste. Therefore, D. brasiliensis is not to be included in the Official List of Threatened Species of Rio Grande do Sul's Flora. 

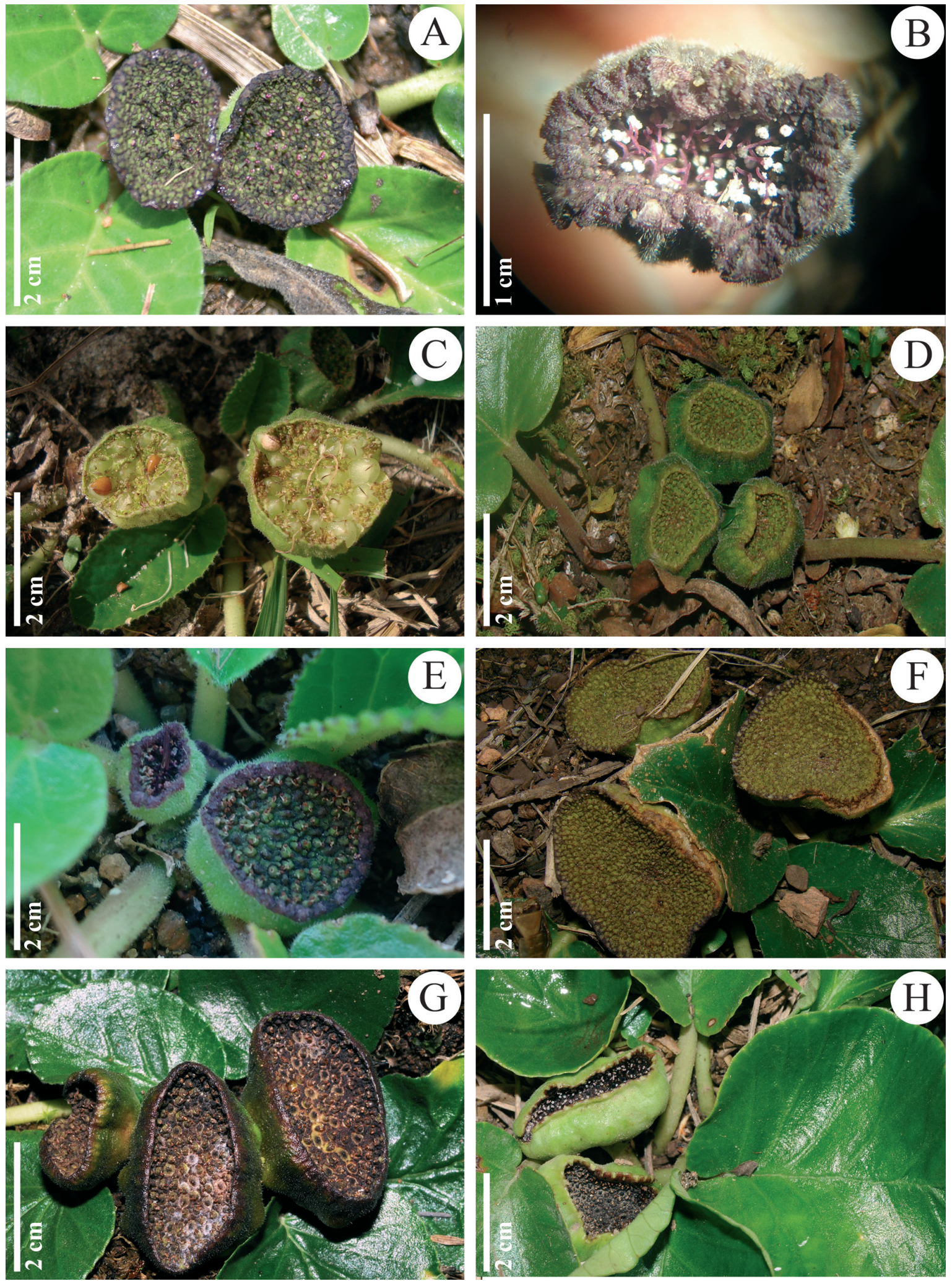

Figure 7 - Morphological variations in coenanthia of Dorstenia brasiliensis, sampled in Rio Grande do Sul, Brazil. Scale bars: A, C, D-H $=2 \mathrm{~cm} ; \mathbf{B}=1 \mathrm{~cm}$. Photos $\mathbf{G}$ and $\mathbf{H}$ : S. Bordignon. 


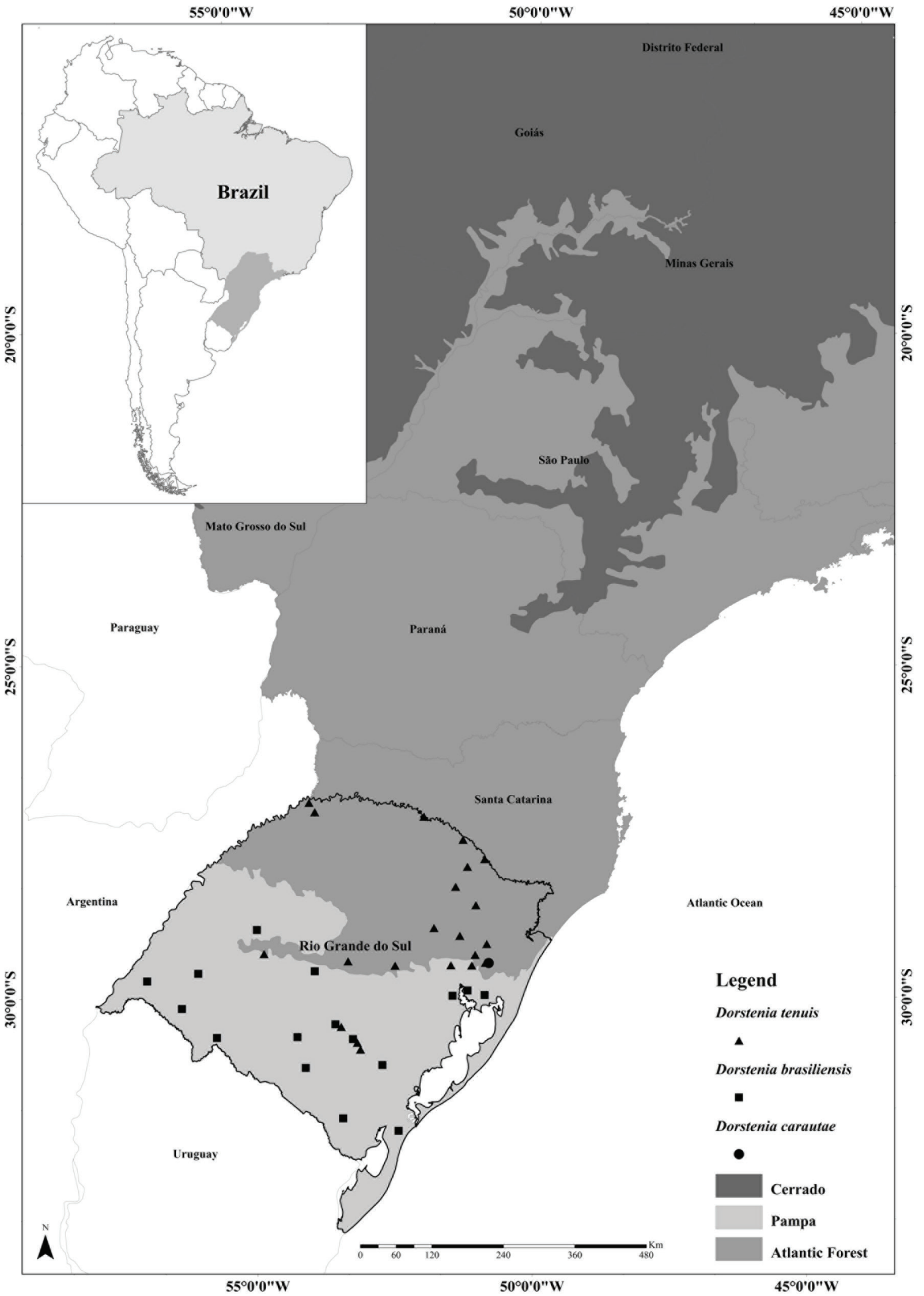

Figure 8 - Distribution map for Dorstenia species native to Rio Grande do Sul, Southern Brazil. 
Notes: Dorstenia heringeri Carauta and Valente and Dorstenia tubicina Ruiz and Pavón are considered synonyms to $D$. brasiliensis by Berg (2001), however, the latter is a valid species at the Lista da Flora do Brasil (Romaniuc-Neto et al. 2014). D. brasiliensis is a highly polymorphic species and widespread in South America. Due to its wide distribution and morphological variation, this species is part of a not well elucidated complex. Berg (2001) in his work for the Flora Neotropica, considered $D$. brasiliensis as a polymorphic species and assumed that the variation in leaf and coenanthia traits were mainly due to environmental variation. Observed morphological variations in coenanthia of Dorstenia brasiliensis, sampled in Rio Grande do Sul are presented on Figure 7.

\section{ACKNOWLEDGMENTS}

This paper is part of the first author's Ph.D. thesis at the Programa de Pós-Graduação em Botânica - Universidade Federal do Rio Grande do Sul (UFRGS). BOB thanks the Coordenação de Aperfeiçoamento de Pessoal de Nível Superior (CAPES) for her scholarship. BOB would also like to thank Greta Dettke and Maria Angelica Kieling Rubio for constructive comments, Marcio Verdi for making the map and Jairo Schwantz for helping in the fields. The curators and staff of the various herbaria cited in the text are acknowledged for their courtesy and loans.

\section{RESUMO}

A sinopse taxonômica de Dorstenia (Moraceae), no Rio Grande do Sul (RS), Sul do Brasil, é apresentado. Três espécies foram registradas: D. brasiliensis, $D$. carautae, um novo registro para o estado do RS, e $D$. tenuis. Todas as espécies são descritas e ilustradas por meio de fotos detalhadas de espécimes vivos. Uma chave taxonômica para separar as espécies, bem como detalhes sobre a distribuição, fenologia geral, habitat, estado de conservação e ecologia são apresentados.
Palavras-chave: Emygdioa, Lecanium, morfologia, América do Sul, taxonomia.

\section{REFERENCES}

Assembléia Legislativa do Estado do Rio GRANDE DO SuL. 2013. Decreto Estadual no 42099/2002, Espécies da flora nativa ameaçadas de extinção no Estado do Rio Grande do Sul. Available in <http://www.al.rs.gov. br/legislativo/Legislação Estadual.aspx $>$ Access in: 15 April 2013.

Berg CC. 2001. Moreae, Artocarpeae and Dorstenia (Moraceae). Flo Neo 7. New York: New York Botanical Garden, p. 144-230.

Berg CC And Hijman MEE. 1999. The genus Dorstenia (Moraceae). Ilicifolia 2: 1-211.

Berg CC AND Simonis JE. 2000. Moraceae. In: Riina R (Ed), Fl Venez. Moraceae-Cecropiaceae: 5-189.

BHL. 2013. Biodiversity Heritage Library Available in: $<$ http://biodiversityheritagelibrary.org/> Access in: 13 September 2013.

Botanicus. ORG. 2013. Missouri Botanical Garden Library. Available in: <http://www.botanicus.org/> Access in: 13 September 2013.

BRUMmitT RK AND Powell CE. 1992. Authors of plant names. Royal Botanic Gardens, Kew, 732 p.

CARauta JPP. 1978. Dorstenia L. (Moraceae) do Brasil e países limítrofes. Rodriguésia 29(44): 53-233.

CARAUta JPP, RomanIUC-NETO S AND SASTRE C. 1996. Índice das Espécies de Moráceas do Brasil. Albertoa 4: 7-23.

FONT-QUER P. 1985. Diccionario de botanica. Editorial Labor S.A., Barcelona.

ForTes AB. 1959. Geografia do Rio Grande do Sul. Porto Alegre: Globo, 393 p.

HARRIS JG AND HARRIS MW. 2001. Plant identification terminology. Utah: Spring Lake Publishing, 206 p.

IBGE. 2012. Manual técnico da vegetação brasileira. $2^{\mathrm{a}}$ ed., Instituto Brasileiro de Geografia e Estatística. Rio de Janeiro: 271 p. <ftp://geoftp.ibge.gov.br/documentos/ recursos_naturais/manuais_tecnicos/manual_tecnico_ vegetacao_brasileira.pdf $>$ Access in: 13 September 2013.

IUCN. 2013. The IUCN red list of threatened species, version 2013. IUCN Red List Unit, Cambridge U.K. Available in: $<$ http://www.iucnredlist.org/> Access in: 21 November 2013.

JSTOR PLANTS. 2013. Available in: http:// http://plants.jstor. org/> Access in: 28 November 2013.

KORNERUP A AND WANSCHER JH. 1978. Methuen handbook of colour, $3^{\text {rd }}$ ed., Methuen, London, 252 p.

Ministério DO MEIO AMBIENTE. 2008. Lista oficial das espécies da flora brasileira ameaçadas de extinção. Available in: http://www.mma.gov.br/estruturas/179/ arquivos/179_05122008033615.pdf> Access in: $1 \overline{5}$ April 2013.

Misiewicz TM AND ZeregA NC. 2012. Phylogeny, biogeography and character evolution of Dorstenia (Moraceae). Edinburgh J Bot 69(3): 413-440. 
Mori SA, Silva LAM, LisboA G AND CoRAdin L. 1989. Manual de manejo do herbário fanerogâmico. Ilhéus: CEPLAC, $104 \mathrm{p}$.

Myers N, MitTermeier R, MitTermeier C, FonsecA G AND KENT J. 2000. Biodiversity hotspots for conservation priorities. Nature 403: 853-858.

Prevedello JA AND CARVAlho CJB. 2006. Conservação do Cerrado brasileiro: o método pan-biogeográfico como ferramenta para a seleção de áreas prioritárias. Nat Conserv 4: 39-57.

RADFORD AE, DiCKINSON WC, MASSEY JR AND BELL R. 1974. Vascular Plant Systematics. New York: Harper \& Row Publishers, 889 p.

RomaniUC-Neto S, CARAUtA JPP, VianNa Filho MDM, PEREIRA RAS, RibeIRo JELS, MACHADO AFP, SANTOS A, Pelissari G AND Pederneiras L.C. 2014. Moraceae. Lista de Espécies da Flora do Brasil. Jardim Botânico do Rio de Janeiro. Available in: <http://floradobrasil.jbrj.gov. br/> Access in: 13 May 2013.
Romaniuc-Neto S, Santos A, Pelissari G, Pederneiras LC, MAURENZA D, BARros FSM, SFAIr JC AND BOVINI MG. 2013. Moraceae. In: Martinelli G and Moraes MA (Eds), Livro vermelho da flora do Brasil. Instituto de Pesquisas Jardim Botânico do Rio de Janeiro, Rio de Janeiro $1^{\mathrm{a}}$ ed., 1100 p. Available in: <http://www.cncflora.jbrj.gov.br/ LivroVermelho.pdf $>$ Access in: 13 December 2013.

THIERS B. 2013. Index Herbariorum: a global directory of public herbaria and associated staff. New York Botanical Garden's Virtual Herbarium. Available in: <http:// sweetgum.nybg.org/ih/>. Access in: 25 September 2009. 